\title{
Comparison of Soft and Hard Clustering: A Case Study on Welfare Level in Cities on Java Island*
}

\author{
Analisis Cluster dengan Menggunakan Hard Clustering dan Soft \\ Clustering untuk Pengelompokkan Tingkat Kesejahteraan \\ Kabupaten/Kota di Pulau Jawa
}

\author{
Nurafiza Thamrin ${ }^{1}$ and Arie Wahyu Wijayanto ${ }^{2 \ddagger}$ \\ 1,2Politeknik Statistika STIS, Indonesia \\ ‡corresponding author: ariewahyu@stis.ac.id
}

Copyright (C) 2021 Nurafiza Thamrin and Arie Wahyu Wijayanto. This is an open-access article distributed under the Creative Commons Attribution License, which permits unrestricted use, distribution, and reproduction in any medium, provided the original work is properly cited.

\begin{abstract}
The National Medium Term Development Plan 2020-2024 states that one of the visions of national development is to accelerate the distribution of welfare and justice. Cluster analysis is analysis that grouping of objects into several smaller groups where the objects in one group have similar characteristics. This study was conducted to find the best clustering method and to classify cities based on the level of welfare in Java. In this study, the cluster analysis that used was hard clustering such as K-Means, KMedoids (PAM and CLARA), and Hierarchical Agglomerative as well as soft clustering such as Fuzzy C Means. This study use elbow method, silhouette method, and gap statistics to determine the optimal number of clusters. From the evaluation results of the silhouette coefficient, dunn index, connectivity coefficient, and $\mathrm{Sw} / \mathrm{Sb}$ ratio, it was found that the best cluster analysis was Agglomerative Ward Linkage which produced three clusters. The first cluster consists of 27 cities with moderate welfare, the second cluster consists of 16 cities with high welfare, the third cluster consists of 76 cities with low welfare. With the best clustering results, the government of cities in Java shall be able to make a better policies of welfare based on the dominant indicators found in each cluster.
\end{abstract}

Keywords: agglomerative ward linkage, fuzzy c means, k-means, k-medoids, welfare.

\footnotetext{
* Received: Des 2020; Reviewed: Jan 2021; Published: Mar 2021
} 


\section{Pendahuluan}

Sasaran utama dari pembangunan di setiap negara adalah peningkatan kesejahteraan masyarakat. Kesungguhan pemerintah dalam usaha mencapai target kesejahteraan tercantum dalam Rencana Pembangunan Jangka Menengah Nasional (RPJMN) 20202024 yang menyatakan bahwa salah satu visi pembangunan nasional adalah mempercepat keadilan dan pemerataan (BAPPENAS, 2019). Menurut (BPS, 2018), jumlah penduduk miskin di Indonesia tahun 2018 diperkirakan sebesar 26,58 juta penduduk atau sebesar $10,12 \%$ dari total penduduk. Pada Agustus 2018 tingkat pengangguran terbuka pada semua provinsi di pulau Jawa naik sebesar 0,395\% secara rata-rata. Jumlah ini akan terus meningkat jika strategi penciptaan lapangan kerja tidak berubah dan mempengaruhi kesejahteraan secara tidak langsung. Permasalahan ini mengindikasikan kebijakan yang kurang tepat sasaran dalam pelaksanaan pembangunan di pulau Jawa. Sehingga perlu adanya identifikasi karakteristik pembangunan berdasarkan tingkat kesejahteraan masyarakat masingmasing daerah untuk terciptanya kebijakan dan strategi yang tepat guna dalam proses percepatan pembangunan. Pengukuran kesejahteraan membutuhkan beberapa indikator yang mendetail dari berbagai aspek. Indikator kesejahteraan rakyat adalah cerminan kualitas sumber daya manusia dari suatu negara yang mencakup indikator pola konsumsi, perumahan dan lingkungan, kependudukan, pendidikan, gizi, kesehatan, pengeluaran dan ketenagakerjaan (BPS, 2018).

Beberapa penelitian telah dilakukan untuk memilih pengelompokkan terbaik. Soemartini \& Supartini (2017) melakukan clustering dengan metode K-means clustering dengan menggunakan indikator kepadatan penduduk, angkatan kerja, laju pertumbuhan penduduk, rata-rata pengeluaran per kapita, angka harapan hidup dan rata-rata lama sekolah. Penelitian lain dari Alwi \& Hasrul (2018) menggunakan metode Average Linkage clustering dengan indikator PDRB tiap kabupaten/kota, jumlah penduduk miskin, kepadatan penduduk, daya beli, jumlah angkatan kerja, angka melek huruf, angka harapan hidup, angka harapan lama sekolah, rata-rata lama sekolah, kepemilikan rumah sendiri, dan tingkat pengangguran terbuka. Hidayatullah (2014) juga menggunakan metode Average Linkage dengan indikator pengeluaran riil perkapita, PDRB perkapita, kepadatan penduduk, angka harapan hidup, dan rata-rata lama sekolah yang mempengaruhi tingkat kesejahteraan.

Analisis komponen utama dilakukan untuk mereduksi data yang awalnya memiliki dimensi yang tinggi (banyak variabel penyusun) menjadi lebih sedikit dengan tetap meminimalisasi resiko kehilangan informasi. Banyak penelitian yang telah membuktikan bahwa penggunaan analisis komponen utama dapat meningkatkan dan mempercepat kinerja metode clustering. Hal ini disebabkan reduksi dimensi dapat menghilangkan fitur yang tidak sesuai serta mengurangi noise dan curse of dimensionality (Izzuddin, 2015; Rahayu \& Mustakim, 2017).

Penelitian ini bertujuan untuk mengelompokkan kabupaten/kota di pulau Jawa berdasarkan karakteristik indikator tingkat kesejahteraan rakyat. Dengan adanya pengelompokkan ini, diharapkan pemerintah dapat menerapkan kebijakan yang tepat untuk terciptanya pemerataan kesejahteraan. Selain itu, penelitian ini juga bertujuan untuk membandingkan beberapa metode clustering yang dapat digunakan untuk mengelompokkan wilayah berdasarkan tingkat kesejahteraan sehingga didapat metode clustering terbaik untuk mengelompokkan kabupaten/kota di pulau Jawa. 


\section{Pendahuluan}

\subsection{Bahan dan Data}

Data yang digunakan dalam penelitian ini adalah data sekunder yang diperoleh dari Badan Pusat Statistik. Penelitian ini menggunakan indikator kesejahteraan rakyat yang didapat dari publikasi indikator kesejahteraan rakyat tahun 2018 dari enam provinsi yang ada di pulau Jawa. Berdasarkan literatur rujukan, maka diputuskan untuk menggunakan sebelas variabel (Tabel 1) yang mempengaruhi tingkat kesejahteraan masyarakat di suatu daerah.

Tabel 1: Variabel Penelitian

\begin{tabular}{clc}
\hline No & \multicolumn{1}{c}{ Variabel } & Tipe \\
\hline 1. & Angka Harapan Hidup & Kuantitatif \\
2. & Angka Harapan Lama Sekolah & Kuantitatif \\
3. & Rata-rata Lama Sekolah & Kuantitatif \\
4. & Daya Beli (didekati dengan pengeluaran per kapita yang & Kuantitatif \\
5. & Angsuaikan) & Kuantitatif \\
6. & PDRB Kabupaten/Kota & Kuantitatif \\
7. Jumlah Angkatan Kerja & Kuantitatif \\
8. & Tingkat Pengangguran Terbuka & Kuantitatif \\
9. Jumlah Penduduk Miskin & Kuantitatif \\
10. Kepadatan Penduduk & Kuantitatif \\
11. Kepemilikan Rumah Sendiri & Kuantitatif \\
\hline
\end{tabular}

\subsection{Metode Penelitian}

Analisis data yang digunakan untuk pengelompokkan kabupaten/kota di pulau Jawa adalah beberapa analisis clustering yang terdiri dari hard clustering (K-Means, $K$ Medoids, dan Hierarchical Agglomerative) dan soft clustering (Fuzzy C Means). Sebelum melakukan clustering, dilakukan pembentukan komponen utama untuk mereduksi variabel yang digunakan.

\section{a. Analisis Komponen Utama}

Principal Component Analysis (PCA) adalah analisis yang berguna untuk reduksi variabel dan sering kali digunakan dalam analisis multivariat. Tujuan dari pembuatan komponen utama ini adalah untuk mereduksi data yang berdimensi tinggi menjadi lebih sedikit dengan tetap meminimalisasi resiko kehilangan informasi. Maka untuk meningkatkan efisiensi, pada penelitian ini akan digunakan metode PCA terhadap dataset asli, sehingga variabel yang berkorelasi akan diubah menjadi komponen utama yang saling independen. Sebelum melakukan PCA, dataset harus dinormalisasi, sehingga skala dari semua variabel sama dan tidak terjadi dominasi antar variabel. Analisis ini juga berperan mengurangi keberadaan outlier dan melepaskan asumsi multikolinieritas (Clayman et al., 2020; Muntaner et al., 2012). Pembentukan komponen didasarkan pada dua cara yaitu matriks korelasi dan matriks kovarian (Johnson \& Wichern, 2002). Proses menentukan komponen utama dengan menggunakan matriks korelasi adalah sebagai berikut: 
1. Membuat matriks $Z_{(n \times p)}$ yang merupakan hasil standarisasi variabel $X$.

2. Membuat matriks korelasi dari $Z$ ( $\left.Z^{\prime} Z\right)$. Hal pertama yang harus dilakukan pada proses reduksi komponen adalah mencari nilai eigen $\left(\lambda_{1}, \lambda_{2}, \ldots, \lambda_{p}\right)$ dari persamaan:

$$
\left|Z_{(p \times n)}^{\prime} Z_{(n \times p)}-\lambda_{(p \times p)} I_{p \times p)}\right|=0
$$

Keterangan :

$\mathrm{Z}$ : matriks hasil standarisasi variabel $\mathrm{X}$.

$\lambda$ : matriks eigen yang merupakan matriks diagonal terssusun oleh eigen value.

I : matriks identitas berukuran $\mathrm{n} \times \mathrm{p}$.

Jumlah komponen utama dipilih berdasarkan eigen value $(\lambda)$ dimana jika $\lambda>1$ maka komponen tersebut akan dipilih sebagai komponen utama (Supranto, 2010). Setelah asumsi terpenuhi selanjutnya dilakukan analisis cluster.

\section{b. Analisis Cluster}

Analisis cluster merupakan pengelompokan beberapa objek menjadi beberapa kelompok dimana setiap kelompok yang terbentuk terdiri dari objek yang mirip di dalam kelompok (Supranto, 2010). Dalam clustering, digunakan ukuran yang menjelaskan kemiripan antar objek (data) untuk menerangkan struktur kelompok yang lebih sederhana dan berasal dari data yang lebih kompleks, yaitu ukuran similaritas dengan menggunakan jarak Euclidean (Johnson et al., 2002). Analisis cluster dibagi menjadi beberapa metode yaitu hard clustering yang terdiri dari metode hirarki dan non hirarki, serta soft clustering dengan menggunakan Fuzzy C Means.

\section{Analisis Hierarchical Clustering}

Hierarchical clustering adalah analisis clustering dengan pengelompokan yang mereduksi kelompok secara sistematis dari $n$ kelompok, $(n-1)$ hingga satu kelompok (metode Divisive) atau sebaliknya secara berjenjang dari satu kelompok, lalu dua kelompok hingga $n$ kelompok (metode Agglomerative). Terdapat beberapa teknik metode Agglomerative diantaranya metode Single Linkage, Complete Linkage, Average Linkage, dan Ward Linkage (Johnson et al., 2002).

\section{Single Linkage}

Single Linkage adalah teknik clustering hierarki dengan menggabungkan objek pengamatan yang memiliki kesamaan terdekat. Metode ini sangat baik untuk melihat cluster bentuk non-elliptical, tapi sangat sensitif terhadap outlier (Govender \& Sivakumar, 2020). Jika terdapat matriks jarak $D=\left\{d_{i j}\right\}$ dan objek koresponden adalah U, untuk membentuk cluster (UV), maka jarak antara (UV) dengan cluster lain misalnya W (Johnson et al., 2002) dapat dirumuskan dengan :

Keterangan :

$$
\mathrm{d}_{(\mathrm{UV}) \mathrm{W}}=\min \left\{\mathrm{d}_{\mathrm{UW}}, \mathrm{d}_{\mathrm{Vw}}\right\}
$$

$\mathrm{d}_{\mathrm{UW}}$ : jarak antara objek $\mathrm{U}$ dan cluster $\mathrm{W}$.

$\mathrm{d}_{\mathrm{VW}}$ : jarak antara objek $\mathrm{V}$ dan cluster $\mathrm{W}$.

$\mathrm{d}_{(\mathrm{UV}) \mathrm{W}}$ : jarak minimum antara cluster UV dan cluster W.

\section{Average Linkage}

Average linkage adalah teknik clustering hierarki yang menggunakan jarak rata-rata antara seluruh pasangan objek dimana salah satu pasangan objek milik masing-masing cluster. Jika matriks $\mathrm{D}=\left\{\mathrm{dik}_{\mathrm{k}}\right\}$ digunakan untuk menentukan objek. Misalnya objek $\mathrm{U}$ dan $\mathrm{V}$ akan bergabung ke cluster (UV) dengan jarak antara cluster UV dan cluster W (Johnson et al., 2002) adalah : 
Keterangan :

$$
\mathrm{d}_{(\mathrm{UV}) \mathrm{W}}=\frac{\sum_{\mathrm{i}} \sum_{\mathrm{k}} \mathrm{d}_{\mathrm{ik}}}{\mathrm{N}_{(\mathrm{UV})} \mathrm{N}_{\mathrm{W}}}
$$

$\mathrm{N}_{(\mathrm{UV})}$ : jumlah objek dalam cluster (UV).

$\mathrm{N}_{\mathrm{W}}$ : jumlah objek dalam cluster $(\mathrm{W})$.

\section{Complete Linkage}

Metode complete linkage merupakan metode clustering hierarki yang mengelompokkan variabel berdasarkan jarak/kesamaan terjauh (berlawanan dengan single linkage), sehingga dua variabel yang memiliki kemiripan terkecil akan ditempatkan pada kelompok pertama dan seterusnya (Johnson et al., 2002). Metode ini menghasilkan cluster yang lebih padat dan lebih robust dibanding Single Linkage (Govender \& Sivakumar, 2020).

\section{Ward Linkage}

$$
\mathrm{d}_{(\mathrm{UV}) \mathrm{W}}=\max \left\{\mathrm{d}_{\mathrm{UW}}, \mathrm{d}_{\mathrm{Vw}}\right\}
$$

Dalam metode Ward Linkage, cluster yang terbentuk memiliki varians internal sekecil mungkin karena jarak antara dua cluster didasarkan pada sum of square dari kedua cluster yang terbentuk. Metode ini juga efektif sehingga sering digunakan dibanding metode hierarki lainnya (Govender \& Sivakumar, 2020). Proses clustering didasarkan pada varians minimum dalam cluster (Johnson et al., 2002). Metode ini biasa digunakan untuk objek dengan jumlah cluster kecil. Proses dalam ward linkage clustering adalah sebagai berikut :

1) Menghitung sum square error antara dua cluster dengan rumus :

Keterangan :

$$
S S E_{i j}=\frac{1}{2} \sum_{k=1}^{p}\left(x_{i k}-x_{j k}\right)^{2}
$$

$S S E_{i j}$ : Sum Squares Error antar pasangan objek $i$ dan $j$.

$x_{i k} \quad$ : nilai objek $i$ pada variabel ke- $k$.

$x_{j k} \quad$ : nilai objek $j$ pada variabel ke- $k$.

2) Mencari nilai SSE terkecil antara kedua cluster lalu menggabungkan menjadi satu cluster. Sehingga dari sebanyak $n$ klaster secara sistematis akan berkurang menjadi $n-1$ dan seterusnya.

3) Mengulangi langkah (2) sampai diperoleh jumlah klaster minimum.

\section{Pemilihan Metode Hierarki Terbaik}

Pemilihan metode hierarki pada penelitian ini menggunakan koefisien agglomerative sebagai ukuran struktur dari cluster hierarki. Nilai koefisien agglomerative yang mendekati 1 menunjukkan struktur yang lebih seimbang dan kuat (Kaufman \& Rousseeuw, 2009). Nilai yang mendekati 0 menunjukkan cluster yang terbentuk lebih buruk. Namun, nilai koefisien agglomerative cenderung meningkat seiring bertambahnya jumlah sampel, sehingga koefisien ini tidak bisa digunakan untuk membandingkan data dengan ukuran yang jauh berbeda.

\section{Analisis Non Hierarchical Clustering}

Analisis clustering non hierarki adalah metode pengelompokan objek ke dalam kelompok sejumlah $\mathrm{k}$ yang telah ditentukan sebelum melakukan analisis. Pada penelitian kali ini menggunakan analisis $K$-means clustering dan $K$-medoids clustering untuk melihat kesesuaian metode dengan data yang digunakan. 


\section{K-Means Clustering}

K-Means clustering adalah metode clustering non hierarki yang paling sederhana dan membagi data ke dalam beberapa kelompok dimana data dengan kesamaan karakteristik dimasukkan ke dalam satu kelompok dan data dengan karakteristik yang lebih berbeda dikelompokkan ke dalam cluster lain (Johnson et al., 2002). Proses dalam K-Means clustering adalah sebagai berikut :

1. Menentukan jumlah cluster (k).

2. Inisiasi secara random nilai centroid (pusat cluster) sejumlah $\mathrm{k}$.

3. Menghitung jarak setiap data terhadap masing-masing centroid cluster dengan menggunakan jarak Euclidean. Jarak euclidean antara objek i dan j dirumuskan dengan :

Keterangan :

$$
d_{i j}=\sqrt{\sum_{k=1}^{p}\left(x_{i k}-x_{j k}\right)^{2}}
$$

$x_{i k} \quad$ : nilai objek ke-i pada variabel ke- $k$.

$x_{j k} \quad$ : nilai objek ke-j pada variabel ke-k.

$p \quad$ : banyak variabel yang diamati.

4. Mengelompokkan data berdasarkan jarak terdekat antara setiap data terhadap centroid.

5. Menentukan centroid baru dengan menghitung rata-rata seluruh data pada pusat cluster yang sama.

$$
C_{k j}=\frac{x_{1 j}+x_{2 j}+\cdots+x_{a j}}{a}, j=1,2, \ldots, p
$$

Keterangan :

$C_{k j} \quad$ : Pusat cluster ke- $k$ variabel ke- $j$.

a : banyak data pada cluster ke- $k$.

6. Kembali ke tahap 3 dan terus melakukan iterasi hingga centroid cluster tetap dan anggota cluster tidak berpindah (konvergen).

\section{K-Medoids Clustering}

Metode K-Medoids adalah pengembangan dari metode K-Means. Seperti yang diketahui, ukuran mean bersifat sangat rentan terhadap keberadaan outlier. Nilai ekstrim pada outlier dapat menggeser rata-rata sehingga distribusinya menjadi tidak normal. Menurut Kaufman \& Rousseeuw (1990) metode K-means sensitif terhadap data yang memiliki outlier akibat penggunaan mean sebagai ukuran pemusatannya. Tidak seperti metode K-Means yang sensitif terhadap adanya pencilan, algoritma $K$-Medoids dapat mengatasi kelemahan tersebut (Arora et al., 2016) karena penggunaan jarak Manhattan yang lebih robust dibanding jarak Euclidian (Gupta \& Panda, 2018). Kedua metode ini menghasilkan sebanyak k cluster yang dibentuk dengan mengukur jarak setiap objek dengan titik pusat, lalu objek dikelompokkan dalam satu cluster berdasarkan titik pusat terdekat.

Prinsip dasar algoritma K-Medoids clustering adalah menentukan $\mathrm{k}$ cluster dari $n$ objek dengan menginisiasi objek random yang dianggap representatif untuk setiap cluster. Titik pusat setiap cluster pada metode ini disebut dengan medoid. Klaster disusun berdasarkan ukuran similarity antara medoid dengan objek selain medoid menggunakan jarak Manhattan. Jarak Manhattan antara objek i dan objek j dirumuskan dengan :

$$
d_{i j}=\sum_{k=1}^{p}\left|x_{i k}-x_{j k}\right|
$$


Proses di dalam algoritma K-Medoids (Gupta \& Panda, 2018) yaitu :

1. Inisiasi secara random $\mathrm{k}$ objek dari $\mathrm{n}$ objek sebagai medoid. Misal medoid dinyatakan dengan $\mathrm{m}_{\mathrm{i}}$.

2. Menghitung jarak antara setiap objek terhadap medoid pada cluster terdekat dan menempatkan setiap objek ke cluster dengan medoid terdekat.

3. Inisiasi secara random objek selain medoid sebagai oi.

4. Menghitung total biaya (cost) dari pertukaran medoid $\mathrm{O}_{i}$ dan Orandom. Dimana Total cost $=\sum \mathrm{d}_{\mathrm{ij}}$

5. Jika $S<0$, maka tukar $m_{i}$ dengan oi untuk dijadikan sebagai medoid baru. Hal ini dilakukan secara iteratif sampai $S$ bernilai konstan (0).

Dimana $S=$ Total cost $t_{\text {baru }}-$ Total cost lama $_{\text {lam }}$

Algoritma yang digunakan dalam K-medoids clustering adalah PAM (Partitioning Around Medoid) dan CLARA (Clustering Large Application). Dimana kedua algoritma ini memiliki prinsip yang mirip. CLARA merupakan pengembangan dari PAM dengan mengandalkan proses pengambilan sampel. CLARA mengambil sampel dari dataset, menerapkan PAM dalam sampel dan mencari medoid dari sampel. Untuk pendekatan lebih baik, CLARA mengambil banyak sampel dan memberikan output terbaik (Gupta \& Panda, 2018).

\section{Fuzzy C-Means Clustering}

Fuzzy C-Means menghubungan derajat keanggotaan dari suatu objek terhadap jarak antara pusat kelompok terhadap objek tersebut. Kelemahan FCM adalah sensitif terhadap noise dan mudah terjebak pada lokal optimum (Izakian \& Abraham, 2011). Keunggulan dari Fuzzy C-Means adalah metode ini robust dalam meminimumkan fungsi objektif (Hadi, 2017; Izakian \& Abraham, 2011). Fungsi objektif pada Fuzzy CMeans dirumuskan sebagai berikut.

Keterangan

$$
\begin{gathered}
J_{m}(\widetilde{U}, v)=\sum_{k=1}^{n} \sum_{i=1}^{c}\left(\mu_{i k}\right)^{m}\left(d_{i k}\right)^{2} \\
d_{i k}=d\left(x_{k}-v_{i}\right)=\left[\sum_{j=1}^{m}\left(x_{k j}-v_{i j}\right)^{\frac{1}{2}}\right]
\end{gathered}
$$

$\mu_{i k}$ : nilai keanggotaan data ke- $\mathrm{k}$ cluster ke- $i$.

$d_{i k}$ : jarak antara titik data ke-k dengan pusat cluster ke-i.

$x_{k}$ : data ke-k.

$v_{i}$ : pusat cluster ke-i.

$m$ : fuzziness, parameter ukuran kesamaran hasil clustering $(m>1)$.

Fuzzy C-Means dapat dievaluasi dengan beberapa ukuran yaitu Partition Coefficient, Classification Entropy Index, Xie and Beni's Index, Separation Index, dan Dunn Index (Wijayanto \& Takdir, 2014).

\section{Partition Coefficient}

Koefisien ini digunakan untuk mengukur jumlah overlapping antar cluster (Grekousis \& Thomas, 2012; Wijayanto \& Takdir, 2014). $\mu_{i j}$ adalah derajat keanggotaan titik data ke-j di dalam kelompok ke-i. Model terbaik dinyatakan dengan nilai PC maksimal. Persamaannya adalah sebagai berikut :

$$
P C=\frac{1}{N} \sum_{i=1}^{c} \sum_{j=1}^{N} \mu_{i j}^{2}
$$




\section{Classification Entropy Index}

Indeks ini mengukur kesamaran dari partisi dalam cluster (Grekousis \& Thomas, 2012; Wijayanto \& Takdir, 2014). Model terbaik adalah model yang memiliki nilai CE minimum. Persamaannya dirumuskan sebagai berikut :

\section{Xie and Beni's Index}

$$
C E=-\frac{1}{N} \sum_{i=1}^{C} \sum_{j=1}^{N} \mu_{i j} \log _{a}\left(\mu_{i j}\right)
$$

Indeks ini mengukur rasio total varians within cluster terhadap separation pada cluster. Model terbaik adalah model yang memiliki nilai XB minimum. Indeks ini dirumuskan sebagai berikut (Grekousis \& Thomas, 2012) :

\section{Separation Index}

$$
X B=\frac{\sum_{i=1}^{c} \Sigma_{j=1}^{N}\left(\mu_{i j}\right)^{m}\left\|x_{j}-v_{i}\right\|^{2}}{N \min _{i, j}\left\|x_{j}-v_{i}\right\|^{2}}
$$

Indeks ini mengukur pemisahan jarak minimum sebagai validitas partisi (Wijayanto \& Takdir, 2014). Model terbaik dinyatakan dengan nilai indeks S yang minimum. Persamaannya dirumuskan sebagai berikut :

\section{Penentuan jumlah cluster}

$$
S I=\frac{\sum_{i=1}^{c} \sum_{j=1}^{N}\left(\mu_{i j}\right)^{2}\left\|x_{j}-v_{i}\right\|^{2}}{N \min _{i, k}\left\|v_{k}-v_{i}\right\|^{2}}
$$

Ada beberapa metode yang dapat digunakan untuk menentukan jumlah cluster optimal pada proses clustering. Dalam penelitian ini, metode yang akan digunakan adalah silhouette method, elbow method dan gap statistic (Clayman et al., 2020). Semua metode ini akan menampilkan plot untuk menentukan jumlah cluster optimal.

\section{Silhouette Method}

Metode Silhouette digunakan untuk memilih jumlah cluster optimal dengan menggunakan data skala rasio. Ketika diterapkan, algoritma silhouette akan mengukur jarak rata-rata dari suatu objek terhadap seluruh objek yang terdapat pada cluster yang sama dengan objek di cluster lainnya. Nilai Silhoutte yang mendekati 1 menunjukkan jumlah cluster yang optimal.

\section{Elbow Method}

Metode Elbow digunakan untuk memilih jumlah cluster berdasarkan siku yang terbentuk pada suatu titik di grafik SSE dan didasarkan pada penurunan SSE yang besar. Jika nilai cluster sebelumnya $(\mathrm{k}-1)$ dengan nilai cluster selanjutnya $(\mathrm{k})$ mengalami penurunan terbesar maka jumlah cluster tersebut yang tepat (k). Metode ini menggunakan nilai Sum of Square Error (SSE) dari masing-masing jumlah cluster. Semakin besar jumlah cluster, maka SSE akan terus mengecil, sehingga jumlah cluster terbaik adalah jumlah cluster yang mengalami penurunan terbesar. Rumus SSE dapat dituliskan sebagai :

Keterangan:

$$
S S E=\sum_{K=1}^{K} \sum_{X_{i}}\left|x_{i}-c_{k}\right|^{2}
$$

$\mathrm{K}:$ cluster.

$x_{i}:$ data ke- $i$.

$c_{k}$ : pusat clusterke-k. 


\section{Gap Statistik}

Gap statistik merupakan ukuran yang paling konstan untuk menentukan jumlah cluster jika dibandingkan ukuran yang lain (Silvi, 2018). Jarak antara objek berpasangan di dalam cluster dirumuskan sebagai :

$$
D_{r}=\sum_{i, i^{\prime} \in C_{r}} d_{i i^{\prime}}
$$

Dimana d adalah kuadrat dari jarak euclidean. Jumlah kuadrat di dalam cluster dirumuskan sebagai berikut.

$$
\begin{gathered}
W_{k}=\sum_{r=1}^{k} \frac{1}{2 n_{r}} D_{r} \\
\operatorname{Gap}_{n}(k)=E_{n}^{*}\left\{\log \left(W_{k}\right)\right\}-\log \left(W_{k}\right)
\end{gathered}
$$

Nilai gap merupakan hasil estimasi jumlah cluster optimum dengan menggunakan pendekatan standarisasi $W_{k}$. Dimana $E n *$ adalah ekspektasi dari distribusi jumlah sampel. Kriteria jumlah cluster optimal merupakan jumlah cluster yang memiliki nilai gap statistik tertinggi atau jika nilai gap selalu naik maka jumlah cluster optimum adalah nilai yang mengindikasi kenaikan gap minimum (Silvi, 2018).

\section{Evaluasi Cluster}

Evaluasi pada cluster terdiri dari evaluasi eksternal dan internal. Dimana evaluasi eksternal dapat dilakukan saat cluster tersebut memiliki label (supervised). Penelitian ini hanya menggunakan evaluasi internal karena data yang digunakan tidak berlabel. Evaluasi internal menggunakan informasi internal pada data untuk menilai hasil clustering. Evaluasi internal mencerminkan kepadatan, hubungan dan pemisahan partisi cluster. Evaluasi internal yang akan digunakan adalah Connectivity coefficient, Silhouette coefficient, dan Dunn Index. Selain evaluasi ini, digunakan juga rasio ratarata simpangan baku within cluster terhadap simpangan baku between cluster.

\section{Internal : Silhouette Coefficient}

Silhouette coefficient merupakan ukuran derajat kepercayaan dalam pengelompokkan suatu pengamatan dengan cluster. Cluster yang terbentuk akan dikategorikan baik jika koefisien yang dihasilkan mendekati 1 dan sebaliknya jika koefisien mendekati angka -1. Silhouette coefficient dihitung dengan cara :

- Menghitung rata-rata jarak antara sebuah objek (I) terhadap setiap objek pada cluster yang sama (kohesi).

$$
a(i)=\frac{1}{|A|-1} \sum_{j \in A, j \neq i} d(i, j)
$$

Dimana $j$ adalah objek selain $i$ dalam cluster yang sama yaitu $A$ dan $|A|$ adalah banyaknya anggota cluster $A$.

- Menghitung rata-rata jarak antara objek $i$ dengan setiap objek pada cluster lainnya lalu ambil jarak terkecil (cluster tetangga terdekat).

$$
\left.d(i, C)=\frac{1}{|A|} \sum_{j \in C} d(i, j)\right)
$$

Dimana $\mathrm{d}(\mathrm{i}, \mathrm{C})$ adalah jarak rata-rata antara objek $i$ terhadap setiap objek pada cluster lain $(C)$ dimana $A \neq C$.

- Selanjutnya menghitung separation yang merupakan jarak dengan cluster tetangga terdekat.

$$
b(i)=\min _{C \neq A} d(i, j)
$$

- Hasil koefisien silhouette dirumuskan dengan :

$$
s(i)=\frac{b(i)-a(i 0}{\max (a(i), b(i))}
$$




\section{Internal : Dunn Index}

Dunn Index merupakan ukuran validasi hasil clustering yang didapat dengan mengukur jarak antara dua cluster dan diameter cluster. Dunn Index merupakan rasio dari jarak terbesar antara dua cluster terhadap jarak terkecil di dalam suatu cluster. Cluster yang terbentuk akan semakin baik saat nilai Dunn index semakin tinggi (Brock et al., 2011). Dunn Index dirumuskan sebagai :

Keterangan :

$$
D I=\min _{i=1, \ldots, k}{ }_{j=i+1, \ldots, k}^{\min }\left(\frac{\operatorname{diss}\left(c_{i}, c_{j}\right)}{\max =1, \ldots, \mathrm{k}\left(\operatorname{diam}\left(c_{m}\right)\right)}\right)
$$

DI : Dunn Index.

$\left(c_{i}, c_{j}\right)$ : jarak antara cluster $i$ dan cluster $j$.

$\left(c_{m}\right) \quad$ : diameter cluster $i$.

\section{Internal : Connectivity Coefficient}

Kepadatan berhubungan dengan mengevaluasi homogenitas dari cluster, biasa dilihat menggunakan varians intra-cluster. Hubungan ini menunjukkan posisi dari data observasi dalam sebuah cluster, yang disebut sebagai tetangga terdekat. Nilai kepadatan tersebut diukur dengan koefisien konektivitas. Nilai connectivity berada di antara nilai nol sampai $\infty$. Cluster yang terbentuk akan semakin baik saat nilai koefisien connectivity semakin rendah (Brock et al., 2011). Connectivity coefficient dirumuskan sebagai berikut :

$$
C C=\sum_{i=1}^{N} \sum_{j=1}^{L} x_{i, n n_{i(j)}}
$$

$n n_{i(j)} \quad$ : tetangga terdekat objek $j$ dari objek di $i$.

$x_{i, n n_{i(i)}} \quad$ : mendekati 0 bila objek $i$ dan $j$ dalam satu cluster dan 1 bila sebaliknya.

L $\quad$ : parameter ukuran jumlah tetangga.

\section{Rasio Rata-rata Simpangan Baku Within Cluster terhadap Simpangan Baku Between Cluster.}

Metode clustering terbaik juga dapat ditentukan dengan menghitung rasio dari rata-rata simpangan baku within terhadap simpangan baku between untuk melihat homogenitas pada cluster terbentuk (Silvi, 2018). Rata-rata simpangan baku di dalam cluster $\left(\mathrm{S}_{\mathrm{w}}\right)$ dan antar cluster $\left(\mathrm{S}_{\mathrm{b}}\right)$ dirumuskan dengan :

$$
\begin{gathered}
\varsigma=\frac{1}{c} \Gamma^{c} \quad \varsigma_{-} \\
S_{b}=\left[\frac{1}{-1} \sum_{k=1}^{c}\left(\bar{X}_{k}-\bar{X}\right)^{2}\right]^{\frac{1}{2}}
\end{gathered}
$$

Dimana $\mathrm{c}$ adalah jumlah cluster dan $\mathrm{k}$ adalah cluster yang akan dihitung. Metode clustering dapat dikatakan baik jika nilai $\mathrm{S}_{\mathrm{w}}$ semakin kecil dan nilai $\mathrm{S}_{\mathrm{b}}$ semakin besar. Metode terpilih memiliki rasio $S_{w} / S_{b}$ terkecil sehingga metode tersebut memiliki homogenitas yang tinggi di dalam cluster.

\section{Hasil dan Pembahasan}

\subsection{Pembentukan Komponen dengan PCA}

Pembentukan komponen dengan PCA akan menghasilkan beberapa komponen yang merupakan kombinasi linear dari varabel-variabel yang digunakan dalam analisis. Komponen yang dapat dilanjutkan dalam proses analisis adalah komponen yang memiliki nilai eigen value $>1$.

Pada penelitian kali ini, terbentuk tiga komponen dengan eigen value lebih dari 1 (Tabel 2). Kemudian analisis dilanjutkan dengan pemodelan clustering berbagai metode dan menggunakan hasil komponen utama sebagai variabel yang akan 
dianalisis.

\begin{tabular}{cc}
\multicolumn{2}{c}{ Tabel 2: Hasil Komponen PCA } \\
\hline Komponen & Eigen value \\
\hline Komponen 1 & 1.7976787 \\
Komponen 2 & 1.4722719 \\
Komponen 3 & 1.1421801 \\
\hline
\end{tabular}

\subsection{Analisis Clustering dengan metode Hierarki.}

Tahap pertama adalah menentukan jumlah cluster (k) optimal yang akan digunakan untuk clustering data dengan metode hierarki agglomerative. Penelitian ini menggunakan Elbow method dan Silhouette method untuk menentukan jumlah $\mathrm{k}$ optimal. Sehingga didapatkan plot seperti disajikan pada Gambar 1.
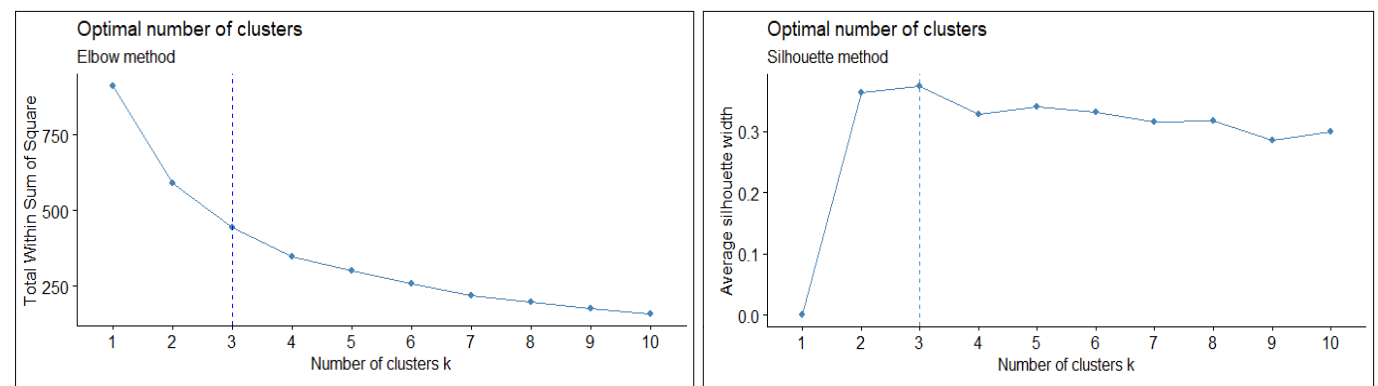

Gambar 1. Elbow method dan Silhouette Method untuk Hierarki Agglomerative

Berdasarkan plot dari Elbow Method, dapat dilihat bahwa patahan gradient terbesar terjadi saat jumlah kaster sebesar tiga. Silhouette method juga memberikan hasil yang sama. Sehingga selanjutnya dapat dilakukan perbandingan metode hierarki terbaik antara metode Single Linkage, Complete Linkage, Average Linkage, dan Ward Linkage dengan beberapa ukuran evaluasi (Silhouette Coefficient, Connectivity Coefficient, Dunn Index, dan Agglomerative Coefficient).

Tabel 3: Evaluasi Metode Hierarki

\begin{tabular}{lllll}
\hline Evaluasi & Ward & Single & Complete & Average \\
\hline SC & 0.3741 & 0.3078 & 0.3689 & 0.3737 \\
CC & 22.6563 & 6.0579 & 17.731 & 16.168 \\
DI & 0.1386 & 0.2234 & 0.1399 & 0.1450 \\
AC & 0.9687 & 0.8116 & 0.9182 & 0.8828 \\
\hline
\end{tabular}

Dapat dilihat dari Tabel 3, Metode Ward Linkage unggul pada Silhouette Coefficient dan Agglomerative Coefficient. Sehingga dapat dikatakan bahwa metode Ward Linkage adalah metode clustering yang memiliki struktur paling seimbang dan kuat dibanding metode lainnya. Sedangkan menurut ukuran Dunn Index dan Connectivity Coefficient, metode terbaik adalah Single Linkage. Sehingga perlu dilihat bentuk cluster yang dihasilkan untuk mendapatkan model terbaik. 


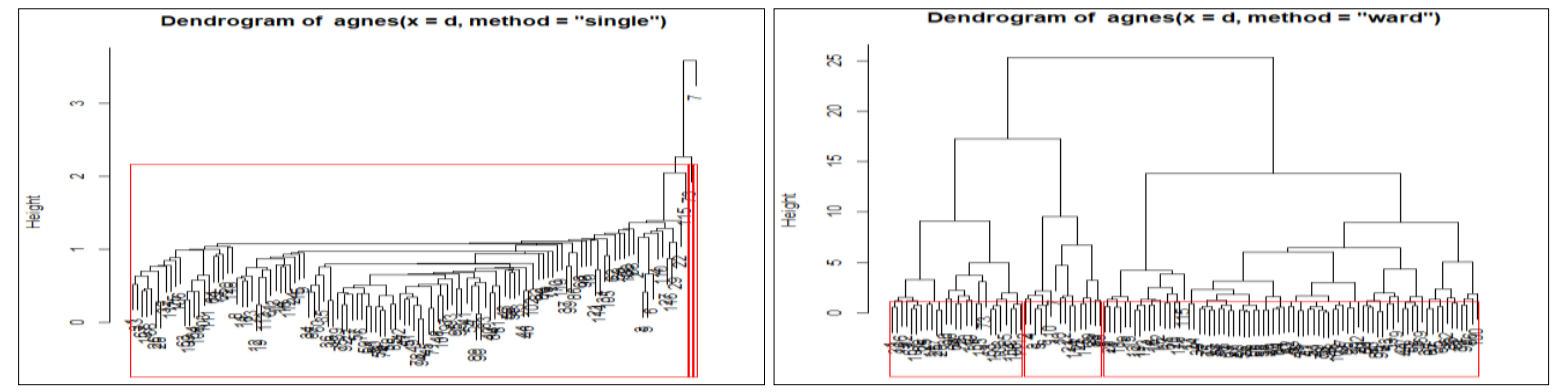

Gambar 2. Dendogram Aglomerrative Metode Single Linkage dan Ward Linkage

Dapat dilihat bahwa struktur dendogram seperti yang disajikan pada Gambar 2, metode Single Linkage memang tidak stabil seperti metode Ward Linkage. Sehingga untuk memperjelas metode terbaik, dilakukan visualisasi hasil cluster yang terbentuk.

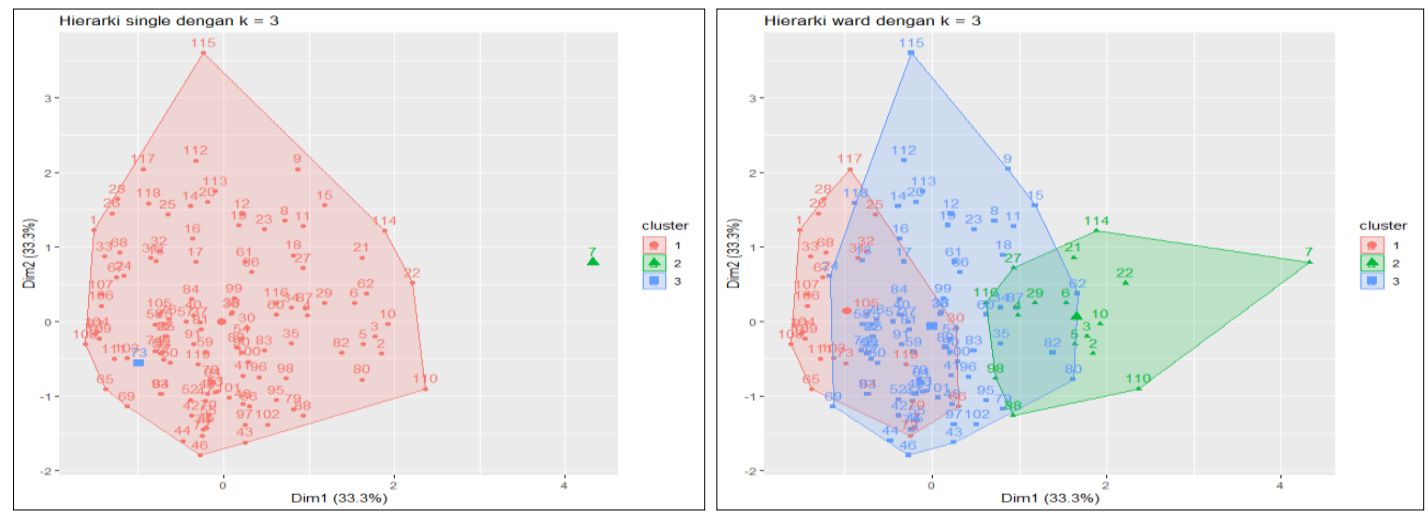

Gambar 3. Clustering Aglomerrative Single Linkage dan Ward Linkage dengan $\mathrm{k}=3$

Menurut hasil clustering, dapat terlihat lebih jelas bahwa Agglomerative metode Ward Linkage mengelompokkan wilayah berdasarkan tingkat kesejahteraan dengan lebih baik dibandingkan metode single karena ketiga cluster tergambar lebih baik dan jelas batasannya (Gambar 3). Oleh karena itu dapat disimpulkan bahwa metode hierarki Agglomerative terbaik yang dapat mengelompokkan kesejahteraan berdasarkan kabupaten/kota di pulau Jawa adalah Metode Hierarki Agglomerative Ward Linkage.

\subsection{Analisis Clustering dengan metode K-Means.}

Sama seperti analisis clustering dengan metode hierarki, langkah pertama yang harus dilakukan adalah menentukan nilai $\mathrm{k}$ yang tepat untuk proses clustering. Pada clustering ini, peneliti menggunakan elbow method, silhouette method dan gap statistic untuk menentukan nilai k optimal.

Berdasarkan plot dari Elbow method (Gambar 4), dapat dilihat bahwa patahan gradien terbesar saat jumlah cluster sebesar empat. Silhouette method menunjukkan bahwa jumlah cluster optimal adalah dua, tetapi jumlah ini terlalu sedikit sehingga digunakan nilai terbesar setelahnya yaitu empat cluster. Berdasarkan plot dari gap statistic ditunjukkan bahwa jumlah cluster optimal sebesar satu, namun jumlah ini tidak sesuai tujuan penelitian sehingga nilai terbesar setelahnya yaitu empat cluster dipilih (Gambar 5). 


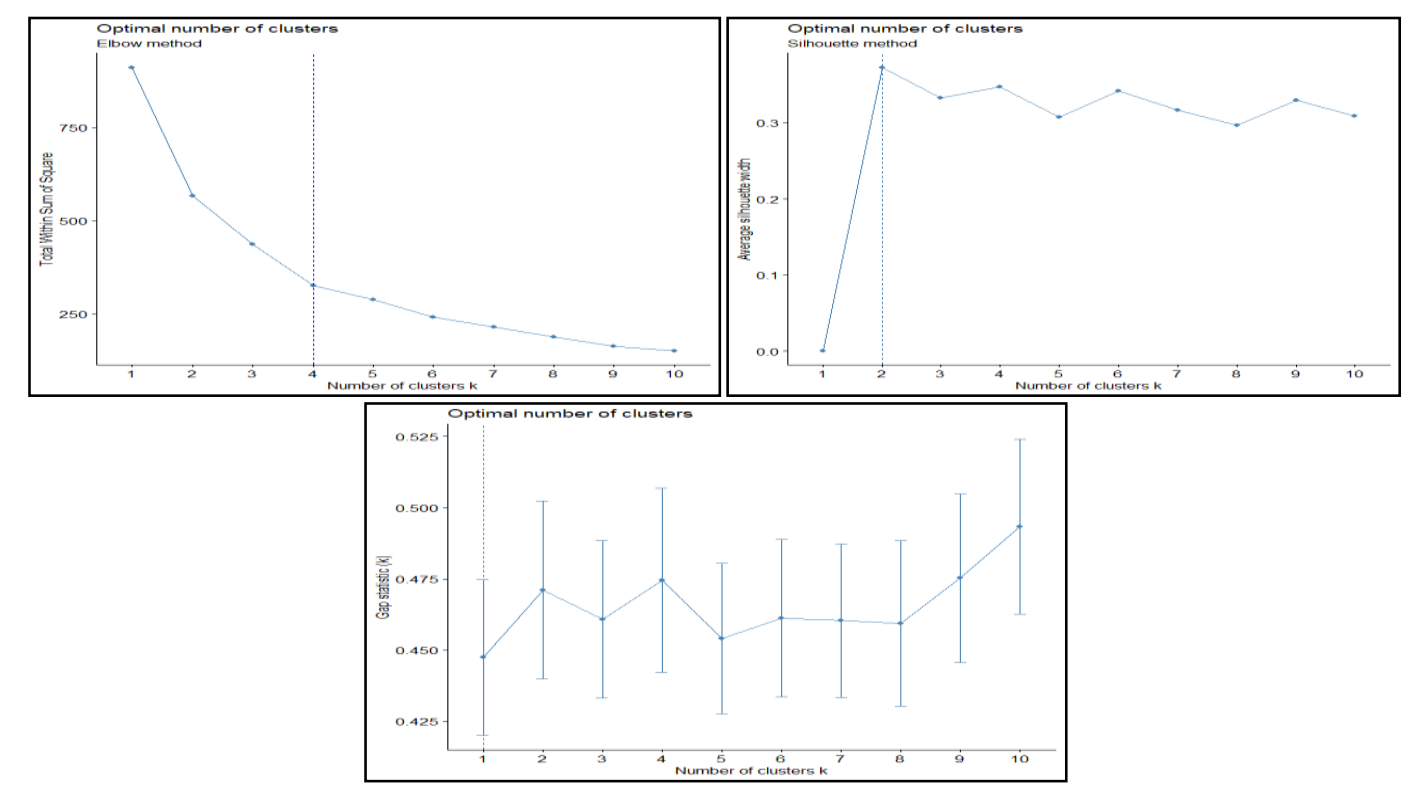

Gambar 4. Elbow, Silhouette, dan Gap Statistic Method untuk K-Means

\subsection{Analisis Clustering dengan metode K-Medoids.}

Algoritma K-Medoids yang digunakan adalah PAM dan CLARA. Seperti metode sebelumnya, hal pertama yang dilakukan adalah menentukan jumlah cluster optimal dengan metode Elbow dan Silhouette untuk algoritma PAM.

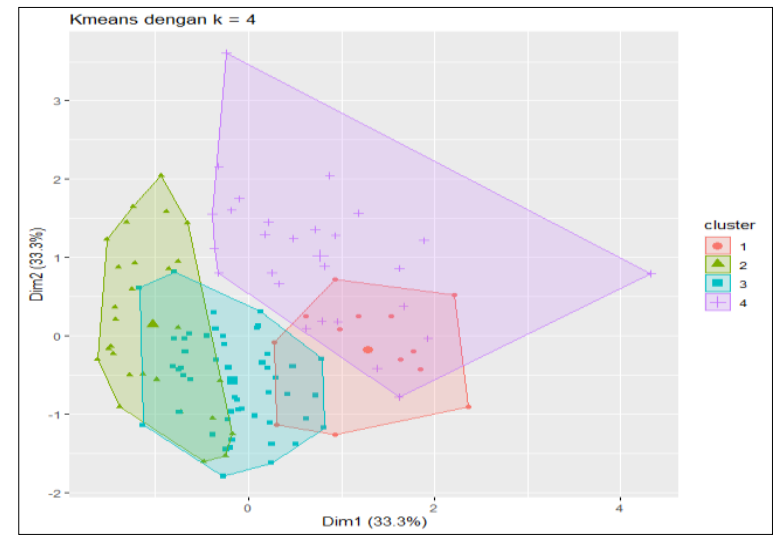

Gambar 5. Clustering K-Means dengan $\mathrm{k}=4$.
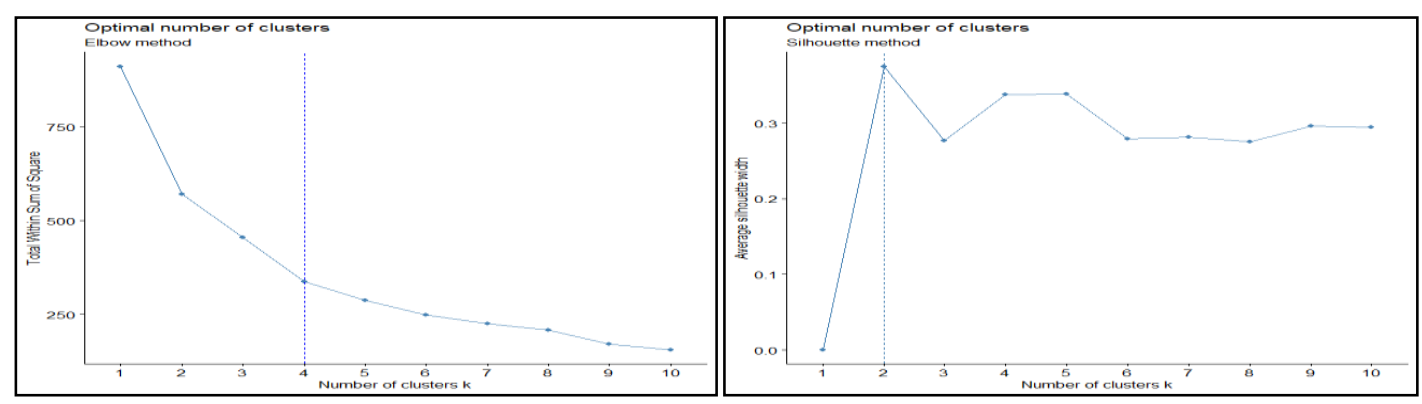

Gambar 6. Elbow Method dan Silhouette Method untuk PAM. 
Plot dari Elbow Method (Gambar 6) menunjukkan bahwa patahan gradien terbesar terjadi saat jumlah cluster sebesar empat. Menurut metode silhouette didapatkan bahwa jumlah cluster terbaik adalah dua, namun jumlah ini terlalu sedikit sehingga jumlah cluster yang digunakan adalah nilai terbesar selanjutnya yaitu saat jumlah cluster sebesar empat. Jumlah cluster optimal untuk algoritma CLARA juga menunjukkan hasil yang sama dengan visualisasi yang sama persis seperti algoritma PAM sehingga tidak ditampilkan. Selanjutnya dilakukan proses clustering untuk melihat hasil cluster yang terbentuk dengan K-Medoids algoritma PAM dan CLARA (Gambar 7).

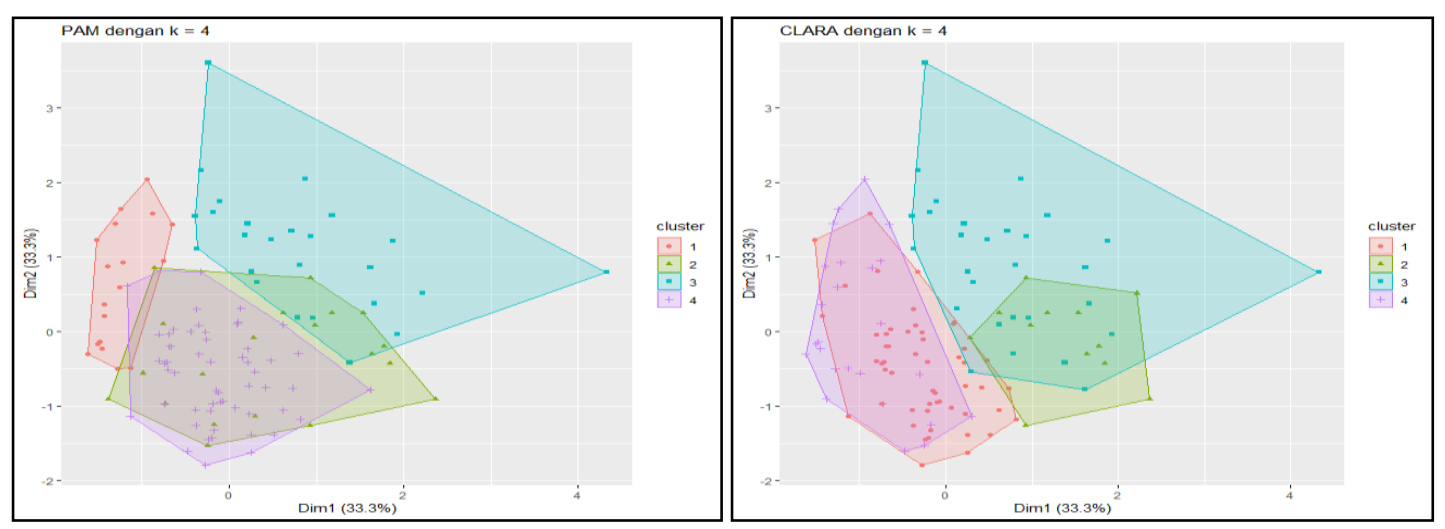

Gambar 7. Clustering K-Medoids algoritma PAM dan CLARA dengan $\mathrm{k}=4$.

\subsection{Analisis Clustering dengan metode Fuzzy C-Means}

Langkah pertama yang harus dilakukan dalam analisis clustering pada umumnya adalah menentukan nilai k. Pada metode Fuzzy C-Means, sama seperti metodemetode sebelumnya akan digunakan elbow method dan silhouette untuk menentukan jumlah cluster optimal.

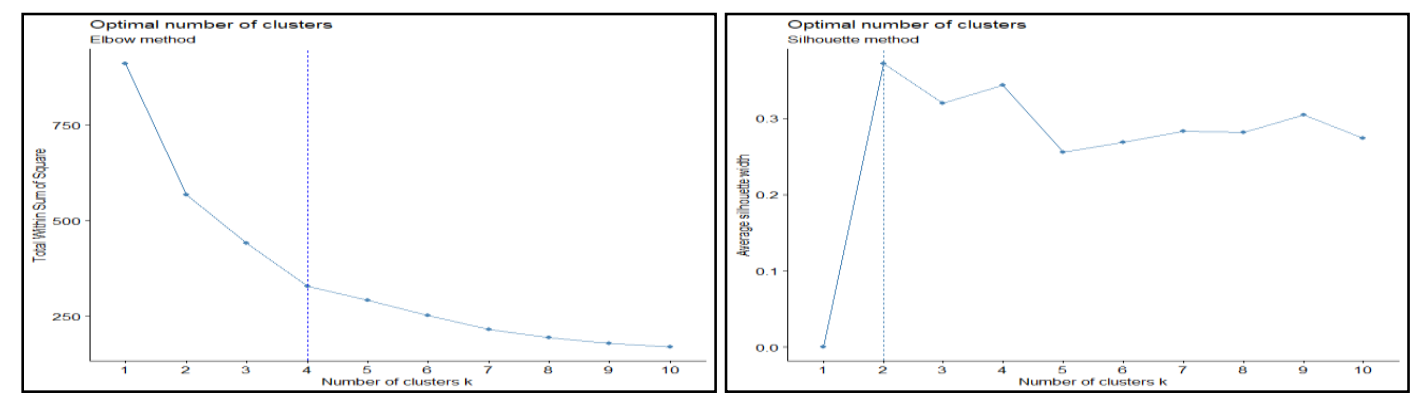

Gambar 8. Elbow Method dan Silhouette Method untuk Fuzzy C-Means

Berdasarkan output dari plot elbow method (Gambar 8), dapat dilihat bahwa patahan gradien terbesar terjadi saat jumlah cluster empat sehingga jumlah cluster terbaik menurut elbow method adalah empat. Sementara silhouette method menunjukkan bahwa jumlah cluster terbaik adalah dua, namun seperti yang dijelaskan sebelumnya jumlah cluster ini terlalu sedikit sehingga dipilih jumlah cluster dengan nilai silhouette terbesar setelahnya yaitu empat. Menentukan jumlah cluster optimal juga dapat dilakukan dengan menggunakan ukuran-ukuran evaluasi untuk jumlah cluster terbaik. Ukuran yang digunakan adalah Partition Coefficient, Classification Entropy, Xie and Beni Index, Separation, Silhouette Coefficient dan Dunn Index. 
Berdasarkan ukuran evaluasi seperti disajikan pada Tabel 4, dapat dilihat bahwa jumlah cluster optimal pada metode Fuzzy C Means adalah tiga cluster. Jika kembali melihat plot Silhouette, jumlah cluster tiga adalah nilai ketiga tertinggi setelah dua dan empat. Sehingga jumlah cluster yang digunakan untuk metode Fuzzy C Means adalah tiga.

Tabel 4: Perbandingan Validitas FCM untuk $\mathrm{k}=3$ sampai $\mathrm{k}=6$ dengan $\mathrm{m}=1.5$

\begin{tabular}{|c|c|c|c|c|}
\hline & 3 & 4 & 5 & 6 \\
\hline PC & 0.810 & 0.780 & 0.719 & 0.720 \\
\hline & 0.353 & 0.422 & 0.550 & 0.564 \\
\hline$X B$ & 0.315 & 0.376 & 0.672 & 0.577 \\
\hline S & 0.255 & 0.289 & 0.490 & 0.411 \\
\hline DI & 0.082 & 0.062 & 0.056 & 0.072 \\
\hline
\end{tabular}

Berbeda dengan metode lain yang langsung dilanjutkan dengan proses clustering. Pada penelitian ini, digunakan threshold sebesar $10^{-6}$. Pada Fuzzy C-Means ini terdapat parameter $\mathrm{m}$ yang harus ditentukan. Sehingga akan digunakan beberapa nilai indeks untuk mengevaluasi m terbaik untuk model Fuzzy C-Means.

Tabel 5: Perbandingan Validitas FCM untuk $m=1.5$ sampai $m=3.5$ dengan $k=3$

\begin{tabular}{lccccc} 
& 1.5 & 2 & 2.5 & 3 & 3.5 \\
\hline PC & 0.810 & 0.565 & 0.453 & 0.398 & 0.370 \\
CE & 0.353 & 0.755 & 0.924 & 1.004 & 1.045 \\
XB & 0.315 & 0.453 & 0.369 & 0.306 & 0.267 \\
S & 0.255 & 0.453 & 0.623 & 0.919 & 1.421 \\
DI & 0.082 & 0.062 & 0.062 & 0.051 & 0.051 \\
\hline
\end{tabular}

Menurut Tabel 5, dapat dilihat bahwa semakin tinggi nilai parameter $\mathrm{m}$, ukuran PC, CE, S, dan Dunn index memburuk. Walaupun pada XB index model terbaik yang diidentifikasi adalah model Fuzzy $C$ Means dengan $m=3,5$. Tapi secara keseluruhan dapat disimpulkan bahwa model terbaik adalah Fuzzy $C$ Means dengan $\mathrm{m}=1,5$ (Gambar 9), sehingga model ini akan dilanjutkan untuk membentuk cluster.

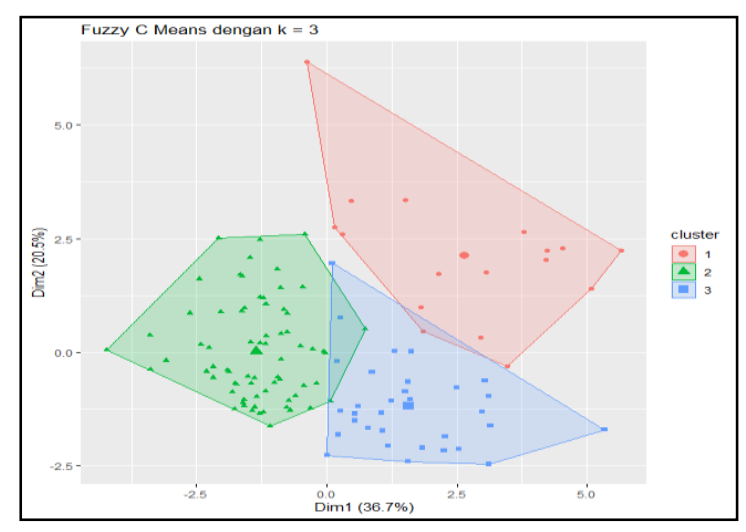

Gambar 9: Hasil Clustering Fuzzy C Means dengan $\mathrm{k}=3$ dan $\mathrm{m}=1.5$ 


\subsection{Hasil Evaluasi Seluruh Metode}

Selanjutnya, evaluasi semua metode yang digunakan untuk mengelompokkan tingkat kesejahteraan rakyat berdasarkan wilayah kabupaten/kota di pulau Jawa. Ukuran evaluasi yang akan digunakan untuk membandingkan semua metode yang diajukan adalah sillhoute coefficient, dunn index, connectivity coefficient, dan rasio simpangan baku within cluster terhadap simpangan baku between cluster.

Tabel 6: Perbandingan Evaluasi Internal Berdasarkan Metode

\begin{tabular}{lcccc}
\hline \multicolumn{1}{c}{ Metode } & SC & DI & CC & $S_{W} / S_{b}$ \\
\hline Ward Linkage $(\mathrm{k}=3)$ & 0.374 & 0.139 & 22.656 & 0.548 \\
K-Means $(\mathrm{k}=4)$ & 0.348 & 0.062 & 43.578 & 0.549 \\
PAM $(\mathrm{k}=4)$ & 0.338 & 0.073 & 40.963 & 0.515 \\
CLARA $(\mathrm{k}=4)$ & 0.325 & 0.058 & 51.849 & 0.524 \\
FCM $(\mathrm{m}=1,5$ dan $\mathrm{k}=3)$ & 0.543 & 0.082 & 41.695 & 0.552 \\
\hline
\end{tabular}

Menurut hasil evaluasi pada Tabel 6, dapat disimpulkan bahwa metode terbaik untuk pengelompokkan tingkat kesejahteraan rakyat berdasarkan wilayah kabupaten/ kota di pulau Jawa adalah metode Agglomerative Ward Linkage dengan nilai Dunn Index maksimum sebesar 0,139 dan Connectivity Coefficient minimum sebesar 22,656. Sedangkan berdasarkan ukuran Silhouette Coefficient, metode terbaik yang bisa digunakan adalah metode Fuzzy $C$ Means dengan $m=1,5$. Rasio varians within dan between menunjukkan bahwa metode terbaik adalah metode $K$-Medoids dengan algoritma PAM. Sehingga interpretasi selanjutnya akan menggunakan hasil clustering dari metode Agglomerative Ward Linkage.

\subsection{Interpretasi Hasil Cluster Metode Terbaik.}

Hasil clustering dari metode Agglomerative Ward Linkage membentuk tiga cluster dengan kabupaten/kota yang terkelompok seperti disajikan pada Tabel 7. Berdasarkan output Tabel 7 dapat disimpulkan bahwa cluster 1 terdiri dari 32 kabupaten/kota dengan tingkat kesejahteraan yang sedang. Cluster 2 terdiri dari 17 kabupaten/kota yang memiliki tingkat kesejahteraan tinggi. Cluster 3 terdiri dari 70 kabupaten/kota dengan tingkat kesejahteraan rendah (cluster terbesar diantara ketiga cluster yang terbentuk). Kategori ini disimpulkan berdasarkan komposisi kabupaten/kota yang terkelompok di dalam cluster. Untuk memastikan hal ini, maka harus dilihat secara univariat dengan menggunakan ukuran rata-rata (Tabel 8).

Cluster pertama adalah kelompok kabupaten/kota dengan harapan lama sekolah yang tinggi dan penduduk miskin yang rendah, tidak ada indikator lainnya yang dominan di cluster ini. Berdasarkan hal ini, dapat dikatakan bahwa cluster ini adalah kelompok kabupaten/kota dengan tingkat kesejahteraan masyarakat sedang.

Cluster kedua adalah kelompok kabupaten/kota dengan angka harapan hidup, rata-rata lama sekolah, daya beli, angka melek huruf, PDRB dan angkatan kerja yang tinggi dimana semua ini adalah ciri daerah dengan kesejahteraan tinggi. Namun cluster ini juga memiliki tingkat pengangguran terbuka, penduduk miskin, dan kepadatan penduduk yang tinggi (tipikal wilayah perkotaan padat penduduk). Berdasarkan hal ini dapat disimpulkan bahwa cluster ini adalah kelompok kabupaten/kota dengan tingkat kesejahteraan masyarakat tinggi. 
Tabel 7: Hasil Clustering Agglomerative Ward Linkage

\begin{tabular}{|c|c|c|c|c|c|c|}
\hline \multicolumn{2}{|c|}{ Cluster 1} & \multicolumn{2}{|c|}{ Cluster 2} & \multicolumn{3}{|c|}{ Cluster 3} \\
\hline $\begin{array}{l}\text { Kepulauan } \\
\text { Seribu }\end{array}$ & Bantul & $\begin{array}{l}\text { Kota Jakarta } \\
\text { Selatan }\end{array}$ & Sukabumi & Kebumen & Pekalongan & Pasuruan \\
\hline Purwakarta & Sleman & $\begin{array}{l}\text { Kota Jakarta } \\
\text { Timur }\end{array}$ & Cianjur & Purworejo & Pemalang & Brebes \\
\hline Kota Bogor & $\begin{array}{l}\text { Kota } \\
\text { Yogyakarta }\end{array}$ & $\begin{array}{l}\text { Kota Jakarta } \\
\text { Pusat }\end{array}$ & Garut & Wonosobo & Situbondo & Jombang \\
\hline $\begin{array}{c}\text { Kota } \\
\text { Sukabumi }\end{array}$ & Kota Kediri & $\begin{array}{c}\text { Kota Jakarta } \\
\text { Barat }\end{array}$ & Tasikmalaya & Magelang & Mojokerto & Nganjuk \\
\hline $\begin{array}{l}\text { Kota } \\
\text { Cirebon }\end{array}$ & Kota Blitar & $\begin{array}{l}\text { Kota Jakarta } \\
\text { Utara }\end{array}$ & Ciamis & Boyolali & Gunung Kidul & Madiun \\
\hline Kota Cimahi & Kota Malang & Bogor & Kuningan & Klaten & Bojonegoro & Magetan \\
\hline $\begin{array}{c}\text { Kota } \\
\text { Tasikmalaya }\end{array}$ & $\begin{array}{c}\text { Kota } \\
\text { Probolinggo }\end{array}$ & Bandung & Cirebon & Wonogiri & Ponorogo & Ngawi \\
\hline Kota Banjar & Kota Pasuruan & Karawang & Majalengka & Sragen & Trenggalek & Pacitan \\
\hline Sukoharjo & Kota Mojokerto & Bekasi & Sumedang & Grobogan & Tulungagung & Tuban \\
\hline Karanganyar & Kota Madiun & Kota Bandung & Indramayu & Blora & Pamekasan & Malang \\
\hline Kudus & Kota Batu & Kota Bekasi & Subang & Rembang & Bangkalan & Gresik \\
\hline $\begin{array}{c}\text { Kota } \\
\text { Magelang }\end{array}$ & Serang & Kota Depok & $\begin{array}{l}\text { Bandung } \\
\text { Barat }\end{array}$ & Pati & Lamongan & Kediri \\
\hline $\begin{array}{c}\text { Kota } \\
\text { Surakarta }\end{array}$ & Kota Cilegon & Kota Semarang & Pangandaran & Jepara & Lumajang & Sampang \\
\hline $\begin{array}{l}\text { Kota } \\
\text { Salatiga }\end{array}$ & Kota Serang & Sidoarjo & Cilacap & Demak & Temanggung & Blitar \\
\hline $\begin{array}{l}\text { Kota } \\
\text { Pekalongan }\end{array}$ & $\begin{array}{l}\text { Kota Tangerang } \\
\text { Selatan }\end{array}$ & Kota Surabaya & Banyumas & Semarang & Banyuwangi & Sumenep \\
\hline Kota Tegal & & Tangerang & Purbalingga & Jember & Bondowoso & Tegal \\
\hline Kulonprogo & & Kota Tangerang & Banjarnegara & Kendal & Pandeglang & Lebak \\
\hline & & & & Batang & Probolinggo & \\
\hline
\end{tabular}

Tabel 8: Rata-rata Variabel Hasil Clustering Agglomerative Ward Linkage

\begin{tabular}{ccccccc}
\hline Cluster & $\mathrm{X} 1$ & $\mathrm{X} 2$ & $\mathrm{X} 3$ & $\mathrm{X} 4$ & $\mathrm{X} 5$ & $\mathrm{X} 6$ \\
\hline 1 & 72.84 & 13.87 & 9.48 & 12784.28 & 97.92 & 24790.28 \\
2 & 73.35 & 13.47 & 10.04 & 14387.94 & 98.34 & 206614.71 \\
3 & 71.98 & 12.52 & 7.00 & 9548.44 & 92.90 & 27579.43 \\
Jawa & 72.41 & 13.02 & 8.10 & 11109.94 & 95.02 & 52405.87
\end{tabular}

\begin{tabular}{cccccc}
\hline Cluster & $\mathrm{X} 7$ & $\mathrm{X} 8$ & $\mathrm{X} 9$ & $\mathrm{X} 10$ & $\mathrm{X} 11$ \\
\hline 1 & 281898.00 & 5.66 & 38.65 & 5253.42 & 74.02 \\
2 & 1303440.24 & 7.18 & 133.39 & 10310.07 & 65.25 \\
3 & 632154.46 & 4.74 & 140.49 & 843.42 & 90.25 \\
Jawa & 633865.82 & 5.34 & 112.09 & 3249.63 & 82.31 \\
\hline
\end{tabular}

Cluster ketiga adalah kabupaten/kota dengan indikator kesejahteraan rakyat yang rendah. Walaupun variabel kepemilikan rumah dan tingkat pengangguran terbuka menunjukkan hasil yang baik, variabel rata-rata lama sekolah, angka harapan hidup, harapan lama sekolah, daya beli, angka melek huruf, PDRB, angkatan kerja berada di bawah rata-rata pulau Jawa. Hal ini menunjukkan capaian yang buruk dalam kesejahteraan masyarakat di kabupaten/kota pada kelompok ini. Sehingga dapat 
disimpulkan bahwa cluster tiga adalah kelompok kabupaten/kota dengan tingkat kesejahteraan masyarakat yang rendah.

Terdapat beberapa kabupaten/kota yang cukup maju dan memiliki industri yang cukup banyak seperti kota Cilegon, kota Yogyakarta, dan kota Pekalongan serta kota yang metropolitan seperti Tangerang Selatan di cluster 1. Pada penelitian ini, adanya overlapping cukup berhasil diatasi dengan metode Fuzzy C Means tetapi berdasarkan hasil evaluasi model, metode terbaik adalah Agglomerative Ward Linkage. Berdasarkan capaian indikator, kota Cilegon memiliki $\mathrm{AHH}$ (66.43 tahun), jumlah angkatan kerja (198809), dan persentase rumah milik sendiri (81.88\%) di bawah ratarata pulau Jawa serta indikator TPT (9.33\%) jauh di atas rata-rata pulau Jawa. Sedangkan kota Yogyakarta memiliki PDRB (26129 ribu rupiah), jumlah angkatan kerja (239542), dan persentase rumah milik sendiri (39.93\%) jauh di bawah rata-rata pulau Jawa serta indikator kepadatan penduduk (13359.31 penduduk per $\mathrm{km}^{2}$ ) dan TPT (6.22\%) diatas rata-rata pulau Jawa. Kota Pekalongan memiliki capaian harapan lama sekolah, jumlah angkatan kerja, persentase kepemilikan rumah milik sendiri dan PDRB di bawah rata-rata pulau Jawa serta indikator kepadatan penduduk dan TPT di atas rata-rata pulau Jawa. Berbeda dengan tiga kota sebelumnya, capaian buruk kota Tangerang Selatan adalah AHH (72.26) yang lebih rendah dari rata-rata pulau Jawa dan kepadatan penduduk (11525 penduduk per $\mathrm{km}^{2}$ ) di atas rata-rata dan mengindikasikan capaian baik pada indikator lainnya tapi terkena efek overlapping yang ada pada penelitian ini. Berdasarkan hal ini, wajar jika kota Cilegon, kota Yogyakarta dan kota Pekalongan dikelompokkan pada cluster pertama (tingkat kesejahteraan sedang) tetapi kota Tangerang Selatan merupakan pengecualian yang disebabkan adanya overlapping pada hasil clustering (kurang crisp) ditandai dengan tumpang tindihnya beberapa kota pada cluster terbentuk.

\section{Kesimpulan}

Metode pengelompokkan yang sesuai untuk indikator tingkat kesejahteraan rakyat kabupaten/kota di Pulau Jawa adalah metode Agglomerative Ward Linkage. Hal ini disebabkan metode ini memiliki struktur cluster yang kuat dan ukuran evaluasi yang lebih baik dibanding metode cluster lainnya (K-means, K-Medoids algoritma PAM dan CLARA, dan Fuzzy C Means). Metode Agglomerative Ward Linkage membentuk tiga cluster dengan rincian :Cluster 1 terdiri dari 32 kabupaten/kota yang memiliki tingkat kesejahteraan sedang dengan angka harapan lama sekolah tinggi dan penduduk miskin rendah, Cluster 2 terdiri dari 17 kabupaten/kota yang memiliki tingkat kesejahteraan tinggi dengan rata-rata lama sekolah, daya beli, angka harapan hidup, angka melek huruf, PDRB dan angkatan kerja yang tinggi namun tingkat pengangguran terbuka, penduduk miskin, dan kepadatan penduduk yang tinggi pula, dan Cluster 3 terdiri dari 70 kabupaten/kota yang memiliki tingkat kesejahteraan rendah dengan variabel $\mathrm{AHH}$, daya beli, $\mathrm{AMH}$, rata-rata lama sekolah, PDRB, angkatan kerja, dan harapan lama sekolah berada di bawah rata-rata pulau Jawa. 


\section{Daftar Pustaka}

Alwi, W., \& Hasrul, M. (2018). Analisis Klaster Untuk Pengelompokkan Kabupaten/Kota Di Provinsi Sulawesi Selatan Berdasarkan Indikator Kesejahteraan Rakyat. Jurnal MSA (Matematika Dan Statistika Serta Aplikasinya), 6(1), 35.

Arora, P., Varshney, S., \& others. (2016). Analysis of K-Means and K-Medoids algorithm for big data. Procedia Computer Science, 78, 507-512.

BAPPENAS. (2019). Narasi RPJMN 2020-2024. BAPPENAS. https://www.bappenas.go.id/files/rpjmn/Narasi\%20RPJMN\%20IV\%2020202024_Revisi\%2018\%20Juli\%202019.pdf

BPS. (2018). Indikator Kesejahteraan Rakyat $2018 . \quad$ BPS. https://www.bps.go.id/publication/2018/11/28/f6adb407ea72d9b66776a270/indika tor-kesejahteraan-rakyat-2018.html

Brock, G., Pihur, V., Datta, S., Datta, S., \& others. (2011). CIValid, an R package for cluster validation. Journal of Statistical Software (Brock et al., March 2008).

Clayman, C. L., Srinivasan, S. M., \& Sangwan, R. S. (2020). K-means Clustering and Principal Components Analysis of Microarray Data of L1000 Landmark Genes. Procedia Computer Science, 168, 97-104.

Govender, P., \& Sivakumar, V. (2020). Application of k-means and hierarchical clustering techniques for analysis of air pollution: A review (1980-2019). Atmospheric Pollution Research, 11(1), 40-56.

Grekousis, G., \& Thomas, H. (2012). Comparison of two fuzzy algorithms in geodemographic segmentation analysis: The Fuzzy C-Means and GustafsonKessel methods. Applied Geography, 34, 125-136.

Gupta, T., \& Panda, S. P. (2018). A comparison of k-means clustering algorithm and clara clustering algorithm on iris dataset. International Journal of Engineering \& Technology, 7(4), 4766-4768.

Hadi, B. S. (2017). Pendekatan Modified Particle Swarm Optimization dan Artificial Bee Colony pada Fuzzy Geographically Weighted Clustering (Studi Kasus pada Faktor Stunting Balita di Provinsi Jawa Timur) [PhD Thesis]. Institut Teknologi Sepuluh Nopember.

Hidayatullah, K. H. (2014). Analisis Klaster Untuk Pengelompokan Kabupaten/Kota di Provinsi Jawa Tengah Berdasarkan Indikator Kesejahteraan Rakyat. Jurnal Statistika Universitas Muhammadiyah Semarang, 2(1).

Izakian, H., \& Abraham, A. (2011). Fuzzy C-means and fuzzy swarm for fuzzy clustering problem. Expert Systems with Applications, 38(3), 1835-1838.

Izzuddin, A. (2015). Optimasi Cluster pada Algoritma K-Means dengan Reduksi Dimensi Dataset Menggunakan Principal Component Analysis untuk Pemetaan Kinerja Dosen. Energy, 5(2), 41-46. 
Johnson, R. A., Wichern, D. W., \& others. (2002). Applied multivariate statistical analysis (Vol. 5). Prentice hall Upper Saddle River, NJ.

Kaufman, L., \& Rousseeuw, P. J. (1990). Partitioning around medoids (program pam). Finding Groups in Data: An Introduction to Cluster Analysis, 344, 68-125.

Kaufman, L., \& Rousseeuw, P. J. (2009). Finding groups in data: An introduction to cluster analysis (Vol. 344). John Wiley \& Sons.

Muntaner, C., Chung, H., Benach, J., \& Ng, E. (2012). Hierarchical cluster analysis of labour market regulations and population health: A taxonomy of low-and middleincome countries. BMC Public Health, 12(1), 286.

Rahayu, G., \& Mustakim, M. (2017). Principal Component Analysis untuk Dimensi Reduksi Data Clustering Sebagai Pemetaan Persentase Sertifikasi Guru di Indonesia. Seminar Nasional Teknologi Informasi Komunikasi Dan Industri, 201208.

Silvi, R. (2018). Analisis Cluster dengan Data Outlier Menggunakan Centroid Linkage dan K-Means Clustering untuk Pengelompokan Indikator HIV/AIDS di Indonesia. JURNAL MATEMATIKA MANTIK, 4(1), 22-31.

Soemartini, S., \& Supartini, E. (2017). Analisis K-Means Cluster Untuk Pengelompokan Kabupaten/Kota di Jawa Barat Berdasarkan Indikator Masyarakat.

Supranto, J. (2010). Analisis Multivariat Arti dan Interprestasi, cet. Kedua. Jakarta: Rineka Cipta.

Wijayanto, A. W., \& Takdir. (2014). Fighting cyber crime in email spamming: An evaluation of fuzzy clustering approach to classify spam messages. 2014 International Conference on Information Technology Systems and Innovation (ICITSI), 19-24. 